821.163.41.09-14 Карановић В. 821.111.09 Колриџ С. Т. https://doi.org/10.18485/sj.2021.26.1.13

НИКОЛА М. БУБАЬА

Универзитет у Крагујевцу

Филолошко-уметнички факултет

ЧАСЛАВ В. НИКОЛИЋ ${ }^{* *}$

Универзитет у Крагујевцу

Филолошко-уметнички факултет
Оригинални научни рад Примљен: 13. 10. 2020. Прихваћен: 12. 1. 2021.

\title{
АУТОПОЕТИЧКЕ БЕЛЕШКЕ И ФАНТАЗМИ ПЕСМЕ: КОЛРИЏОВЕ УВОДНЕ НАПОМЕНЕ О „КУБЛАЈ КАНУ” И „РАЗЈАСНИЦА” ВОЈИСЛАВА КАРАНОВИЋА
}

У истраживању представљеном овим радом спроведено је напоредо тумачење уводне, а накнадно додате, напомене песми „Кублај Кан” (1816) Семјуела Тејлора Колриџа и аутопоетичког коментара песама „Брод” и „Тhe Ship” у виду „Разјаснице” (1989) Војислава Карановића. Уочавајући, обележавајући и идентификујући подударне и особене метапоетичке перспективе двају пропратних записа о песмама, а уводећи у мишљење и вредности тим записима осветљених песама, настојали смо не само да кажемо нешто о идеји апсолутне песме која имагинацију запоседа као фантом о сусрету песничког исказа са својим бићем, већ да представимо и природу саме лингвистичке материјализације (напомене, коментара, разјаснице, метајезика) као фантазма. Измицање и признање губитка фантомске песме, и код Колриџа и код Карановића, рађају фантазматско кружење језика око места онога што је као биће, почетак и порекло самог певања, ишчезло. Ипак, текстови разјаснице јесу и нешто више: прозор кроз који се материјали-

*nikola.bubanja@filum.kg.ac.rs

*** caslav.nikolic@filum.kg.ac.rs 
зоване речи, прихватајући свој недостатак, подижу у ваздух и, као остатак над празнином о коме треба мислити и говорити, почињу да лебде.

Кључне речи: Колриџ, Карановић, аутопоетика, метапоетика, белешка, разјасница, фантазам, језик.

\section{ФАНТАЗАM}

Појам фантазам (транслитерује се и у облик именице женског рода „фантазма”) има значење које се, с обзиром на етимолошку повезаност са речима попут „фантазија”, лако наслућује у општем смислу: „привиђење, утвара, обмана, опсена” (РМС 2011: 1401, одредница „фантазма”, значење a). Међутим, у овом тексту имамо у виду нешто специфичнија значења овог појма, везана за 1. старе неоплатонске теорије о процесу виђења (очима) и за 2. идеју фантазма као спектралног простора конституисања жеље.

Прво од наведених значења може се илустровати стиховима песме „Екстаза" Џона Дана ("Extasie" - екстаза је била неоплатонски концепт привременог изласка душе из тела - ex + stasis, односно „стајати изван”): „зраке из очију смо спрели и уденули / очи двоструком нити" ("Our eye-beams twisted, and did thread / Our eyes upon one double string", стихови 7 и 8, прев. Н. Б). Стихови одсликавају барокну екстраваганцију, али и прецизност Данове слике - у томе je, заправо, посебна димензија њене екстраваганције. Прецизност слике преплетених зрака из очију као у очи уденутих конаца, која се иначе може учинити натуралистички морбидном, произилази управо из неоплатонске филозофије виђења или процеса вида.

Наиме, процес виђења објашњавао се идејом постојања невидљивих зрака које су очи, по претпоставци, емитовале ка објекту гледања (види Хант 1956: 62-63). Ти зраци имали су, да се послужимо терминологијом научно-фантастичног филма, улогу „вучног зрака”, који су слику објекта гледања привлачили ка очима: та „слика” објекта гледања је његов „фантазам” (ibid.). Сваки предмет посматрања има, опет, мноштво фантазама које погледи скупљају и допремају до субјекта (ibid.). У том смислу, петраркистички мотиви слике у оку и слике у срцу имају заправо прецизно значење које се временом редуковало на стереотип (ibid.). Пошто зраци из очију субјекта привлаче само рефлексије предмета посматрања, поглед субјекта и, консеквентно, субјект сам, никада није у поседу самог објекта гледања, већ само једног од његових фантазама. По аналогији, дакле, појмом фантазма у овом тексту означавамо „,аватаре”, репрезенте, одразе, јеку песме коју је једино посредством њих могуће у било ком смислу имати и доживети (изгледа, чак и ако сте њен аутор). 
Фантазам није само остварење жеље, већ њено конституисање, па како је ,жеља структурисана фантазмом”, онда се фантазам може одредити као „имагинарни сценарио који представља остваривање жеље” (Цветић 2011: 71). Жеља се не усредсређује на стварне, већ на фантазматске објекте, јер носећи „остатке сећања”, жеља у фантазму само „успоставља везу са ситуацијом и начином првог (или претходног) задовољења” (Цветић 2011: 70). Тако је и савремена српска поезија - како стихове Војислава Карановића чита Саша Радојчић - „налик на разгледницу упућену на адресу непостојеће особе која живи у непостојећем граду непостојеће земље. Говор из празног места упућен негде у неодређену празнину” (Радојчић 2005: 105). Песме су, отуда, више од песничких слика, јер су увид у то како се задобија и како се губи животни амбијент: „Искази о свету кога почињемо да разумевамо тек пошто нам је измакао, и сада му пишемо разгледнице, на непостојећу адресу. Док стигне наша посланица, ко ће нам још веровати да смо били, под овим сунцем?" (Радојчић 2005: 112) За Жака Лакана, фантазам је „уметак, формација која прекрива одређени јаз/празнину" (Жижек 2006: 232). Објекат жеље увек је „уобразиљски, тј. халуцинатогени”, па то и није „објект по себи”, већ онај објект за којим субјект „жуди, јер верује да ће му он пружити задовољење” (Јевремовић 1998: 18). Како је објект жеље одсутан, већ изгубљен, то се и у односу са ишчезлом ствари показује недостатак бића. Јер што се „субјект више појављује, што се симболички више уписује у поредак Другог, то ће он, са друге стране, све више копнити, ишчезавати, нестајати, одумирати" (Јевремовић 1998: 237).

Пошто његова жеља конституише фантазам, субјект се уписује у фантазматску структуру, али је присуство субјекта у фантазму парадоксално. Као биће уживања, субјект је одређен принципом задовољства који се изокреће у принцип незадовољства, па само задовољство „подиже баријеру свеколиком jouissance” и изазива нелагоду: „Ако превише уживам у нечему, врло брзо ћу осетити нелагоду и умерићу своје уживање. Изгледа да је организам начињен да избегава превише јouissance" (Лакан 1988: 228, према Цветић 2011: 71). Али то што, као принцип задовољства, с једне стране перманентно измиче, с друге се изнова враћа као уживање у ономе што је „иза принципа задовољства" - у фантазматској конструкцији као у оном објекту који је недостижан, „који се не може имати, али на чијем се немању гради сопствено ја” (Цветић 2011: 72). Тако постојање жеље и природа њеног објекта, као онога што се не може достићи дефинишу начин на који се субјект односи према свету тако да снагу фантазије концентрише на месту непостојећег објекта жеље: „Објект жеље заузима посебно место у симболичком поретку и прави процеп између реалности жеље и реалности свакодневног живота и тај процеп постаје место фантазије” (Цветић 2012: 76). Жеља је „конфликтима неминовно растрзана чињеница постојања", па је поводом жеље, по психоанализи, увек реч о кон- 
фликту „између жеље (дакако неостварљиве жеље) и за њу у основи осујећујуће реалности" (Јевремовић 1998: 16). Субјекту мора остати недоступна његова „темељна фантазма - у тренутку када се сувише приближи тој фантазмичкој језгри, субјект губи конзистентност свога постојања" (Жижек 2006: 54). Ако се жеља креће око места стално измичућег, непоседованог, недостижног и несимболизованог објекта, око места на коме објект изостаје, онда је задовољство „ближе болу”, те лакановско искуство ,' иза принципа задовољства” води субјекта на „'пут ка смрти"” (Цветић 2011: 72).

Када се извесна представа формира у оку, односно у погледу субјекта, тада слика, као израз светлости, почиње да посматра субјекта, па је он тај који се настањује у слици. Одвајајући се од погледа, који сада омогућава да субјект постане видљив, субјект и његова жеља неистоветни су погледу, па је то што субјект жели „нешто друго, а оно што му се нуди да види није оно што он жели" (Цветић 2011: 74). А где год је реч о изостанку жељеног, о дисконтинуитету и распуклини у искуству, као ефекат тог расцепа и фрагментираности бића, профилише се фантазам. У лакановском смислу, сама „спектралност је друго име за фантазмички привид који испуњава несводиви онтолошки јаз" (Жижек 2006: 214). Природа фантазматског испољава се у покушају да се расцеп „препокрије”, да се „профилише искуство” и, преко фантазма, учини организованим, компактним, схематизованим, интегрисаним (Јевремовић 2012: 140). Виртуална, фантазматска интеграција још „није прича”, али „тежи причи” (Јевремовић 2012: 142). Може ли пролазак кроз фантазам заиста означити „субјектово (симболичко) поновно рођење, његову (ре-)креацију ex nihilo, скок кроз 'нулту точку' нагона смрти према потпуно новој симболичкој конфигурацији његова бића” или фантазам само „застире чињеницу да је субјект већ посве 'без коријена', да је његова права позиција празнина универзалности" (Жижек 2006: 189, 193)? Да ли се у аутопоетичком дискурсу, особито онда када текстови разјаснице непосредно прате песме о којима говоре, потврђује увид по коме „заснивање субјекта као биће које говори", симболичка афирмација и отуђење на месту Другог, откривају да су мањак и смрт ствари, „нестанак ствари у њеном симболичком појављивању”, то што поетика препознаје у структури свог симболичког поретка? Намерни смо стога да покажемо, дакле, како се текст прозног записа песника Војислава Карановића о његовој песми „Брод”, баш као и енглески и српски текст исте песме, чита као један њен фантазам. Јер „могло се”, како о томе говоре стихови Карановићеве песме „Писмо Хелдерлину”, „и без говора, не познајући реч / у себе тонути”, па у том потонућу незнања језика „радовати се, заиста, томе се радовати” (Карановић 2020: 22). И мада је језик „велика сувишност”, a „нема се томе шта додати”, ипак у песми „Поезија настаје” језик је то што се дешава, па субјект пише, песма се облачи у језик и омогућава да из мрље један човек потрчи, а онда да у тој мрљи нестане. Мисао о човеку јесте мисао о тој мрљи: „ко је тај човек/из те мрље” (Карановић 2020: 17). 


\section{АУТОГРАФСКА БЕЛЕШКА}

У овом тексту занимамо се искључиво за аутографске белешке (које је забележио сам аутор, о свом тексту), међу којима разликујемо оне номиналне, и оне архивске. Под архивском белешком подразумевамо нацрте, раније верзије, рукописе, необјављене или незавршене текстове који могу бити предмет накнадне археологије предузете у приватним или јавним архивима. Оно што их чини, по нашем суду, архивским, јесте јасно формално одређен статус трајне одбачености (од стране аутора). Унутар тако постављених ограда, налазимо још да постоје или да су постојали и незавршени текстови који нису задржали облик било каквог записа, те се не могу наћи ни у једном архиву (али би се у архиву налазили, да су сачувани као записи). У том смислу би се могло говорити и о фантомској белешци, као врсти несачуване архивске белешке-тексту забележеном да буде залог потоњих текстуалних исхода који ће га натписати, палимпсестизирати - одупрећемо се нагону да кажемо „избрисати” (јер шта се то још може заиста избрисати, до ништења).

Под номиналном белешком, пак, подразумевамо белешку које се као таква идентификује и објављује: „скицу”, „нацрт”, „увод”, па тако и „Разјасницу” Војислава Карановића, сматрамо номиналном белешком. Жанру номиналних бележака у овом смислу би припадали и текстуални фрагменти какви су накнадне ауторске напомене, фусноте, глосе и краћа објашњења - сваковрсне аутографске перитекстуре. Све накнадне аутографске (па и алографске, али овде исте свесно остављамо по страни) белешке, а посебно оне које имају текстуални облик целине - тела текста обележеног насловом, сматрамо продужецима, односно ревизијама оригиналног текста. О том феномену смо писали као о продукту анксиозности или трауме одвајања аутора од текста, слања текста од себе - односно недовршености текста (Бубања 2015).

\section{УТВАРЕ КАО НЕДОВРШЕНИ ТЕКСТОВИ}

Да, показно, натпишемо и себе, писали смо (Бубања 2015) о томе како и читаоци и аутори теже искуству краја и наводили Кермодов (44-45) пример ове потребе: звуковност откуцаја часовника наводно ономатопејски приказујемо као „тик-так”, иако је звук увек „тик-тик” - увек је исти, нема промене. То радимо, каже Кермод (ibid), да бисмо организовали откуцаје у опозиције почетка и краја, које нам помажу да фиктивно омеђимо тренутак, да доживимо његов крај и тиме дамо смисао времену. У наведеном тексту, устврдили смо (Бубања 2015) да су „на концу, сви текстови напуштени [прекинути]': сви су они предмети таштине, несигурности, који се стрпљиво трпе [игноришу]

\footnotetext{
${ }^{1}$ У великим заградама су мале допуне, које бих данас додао.
} 
или с којима се периодично преговара" ("ultimately all texts are abandoned: they are all items of vanity and insecurity, and they are either patiently endured, or periodically renegotiated").

У овом смислу смо (Бубања 2015) испод Поовог постулата о јединству ефекта и инсистирању на релативној сажетости песме, осећали ургентност инсистирања и пледирања усмерених ка ефикасности кушања текста, односно његовог довршавања. У смислу опреза при процени значаја динамике тока и прекида читања наводили смо праксе експликације текста у настави, као и рад на обимнијим научним текстовима, попут дисертација, где је суочавање са прекидима и аветима ненаписаног неизбежно. И посебно, наводили смо примере накнадних ауторских бележака о текстовима: накнадни коментар Исака Асимова о историји публиковања приче „Очи нису само да гледају”, коју је првобитно одбио Плејбој, што је повредило ауторов осећај сатисфакције исходом тог текста довољно да о њему напише предговор дужи од текста приче, у коме набраја његове успехе и у прикривеној самоодбрани ликује: „,a како вам се то свиђа, господине Хефнер.” То је ликовање истеривача (текстуалних) духова после успешног погубљења, ценили смо. Но, за овај текст нам се чини релевантнијим, тада у осврту дато (Бубања 2015) тумачење, у истом кључу, Колриџовог накнадно написаног описа настајања његове песме „Кублај Кан”, које овде желимо да прочитамо напоредо са „Разјасницом” Војислава Карановића.

\section{„КУБЛАЈ КАН”, THE SHIP, „БРОД” И ЊИХОВЕ РАЗЈАСНИЦЕ}

У горе нареченој, накнадно објављеној аутографској белешци, Колриџ је за песму „Кублај Кан” устврдио да је фрагмент (реч фрагмент је уградио и у наслов, чији пуни облик гласи „Кублај Кан, сновиђење, фрагмент”) - тек део велике поеме коју је сањао па почео да записује кад га је неки посетилац прекинуо, због чега касније, упркос бројним покушајима, није успео да забележи песму до краја. На тај начин, Колриџ креира (Перкинс 2010: 39) „мит о изгубљеној песми... чији непостали стихови походе имагинацију више него што би било која постала песма могла" ("...the myth of the lost poem ... The nonexistent lines haunt the imagination more than any actual poem could"). Дакле, Колриџов опис настанка песме схватили смо као још један покушај да се она напише, да се авет незавршеног текста упокоји. Пошто њену „хармонију и цјеловитост више нитко не може прихватити", од романтизма се трансценденција може слутити само „у дисонанцама и одломцима” (Фридрих 1969: 22). Чинови разлагања, раздељивања и деформирања збиље, како би се из фрагментаризацијом добијених делова створио нови свет, утемељујуће су вредности 
модерне естетике. Из онога што је разорено не може се успоставити „свијет реално уређен”, већ „иреална творевина” која не подлеже поретку реалности. Модерност „на почетак умјетничког чина ставља разлагање”, а овај поступак разарања Бодлер потенцира тако што појам „,' разлагати' замјењује с 'дијелити”" (Фридрих 1969: 44). Дереализација ствари у модернистичкој књижевности спроведена је како се би се онестваривањем ствари „до потеза, боја, покрета, до тих осамостаљених акциденција” на њих излило „, магично свјетло ”, што би учинило „да њихова реалнност завршава у тајни” (Фридрих 1969: 45).

Овде бисмо напоменули мало коинцидирање Колриџовог објашњења песме „Кублај Кан” (1816) и „Разјаснице” (1989) Војислава Карановића. Колриџ, наиме, описује како је непосредно пре песмотворног сна читао Пурчисова ходочашћа (пуним, оригиналним насловом Purchas, his Pilgrimes, or Relations of the World and Religions Observed in All Ages and Places Discovered, from the Creation to the Present) аутора Семјуела Пурчиса, који је, између осталог, писао и о Занадуу (локалитету из Колриџове песме) и о Кубла Кану. Карановић, иако не напомиње да је читао Семјуела Пурчиса, напомиње како је пре записивања песме The Ship интензивније читао енглеске песнике, на енглеском:

Носећи у себи магловиту слутњу будуће песме, догодило се да сам интензивније читао неке енглеске песнике. Једне вечери, заморен читањем на енглеском, сео сам за хартију не бих ли нешто написао. Мало-помало, готово неопазице, песма чију сам магловиту слутњу носио у себи попримила је одређенији обрис; обукла се у језик, али -у енглеске речи (Карановић 2020: 20).

Признајемо, читање енглеских песника није баш тако егзотично као читање Семјуела Пурчиса; слажемо се и да „заморен читањем” није исто што и, отприлике, „заспао уз књигу и нешто опијума" (Колриџ напомиње да је, због здравственог проблема, користио анодајн, а сумња да је то шифра за опијум је опште место). И, најзад, то што се магловита слутња песме неопазице обукла у језик далеко је од Колриџове приче о сачињавању песме у сновиђењу и њеног записивања одмах по буђењу. А ипак, чини нам се, приказани процеси су голицаво слични, јер отвореније или суптилније говоре о мистификацији или ремистификацији поетског стварања. Карановићево песничко биће, разумљиво, тражи језик којим би се та мисао обукла у ново рухо, јер та мисао није само, па ни првенствено итеративна: зато он (Карановић 2020: 21) одбацује проказана имена заноса, инспирације, надахнућа, али се истовремено пита „откуда поезији то осећање кривице и стида када се поведе реч о тајни и о оном необјашњивом што и чини њену суштину?” Одбацујући старе фантазме романтичарске поетике, песник жели да сачини нови, адекватан осећају недовршености и отклона према претходном. И заиста, орфичко и мистично надопуњује се мистичном интертекстуалношћу, оним што Драган Бошковић (2000) назива текстуалном епифанијом песама на енглеском: то „није колаж мобилних текстова на енглеском, нити палимпсест, него несвесно и необич- 
но искуство епифаније, предетерминација нове песме читањем претходних песама".

Преиспитивање могућности песничког језика, нарочито „у контексту продубљеног, метафизички инспирисаног поетског односа према језику и свету", у знаку је парадоксалног преплитања поверења у језик и онтолошке сумње језик: „Посебност Карановићеве позиције је у томе што се његова сумња не тиче само могућности исказивања, дакле функције језика као инструмента посредовања субјекта и света, него иде много дубље, и захвата основне начине постојања тог субјекта и тог света" (Радојчић 2005: 107). Усколебаност у препознавању „стварност света, субјекта и песме” особено је „духовно стање” из кога, по Саши Радојчићу, „извиру Карановићеви стихови” (Радојчић 2005: 108). Истинска поезија, по речима самог Карановића, својим погледом продире кроз велове у које је постојање умотано, налазећи у самом том проласку кроз засторе, у чежњи да ступи у оно иза свој утемељујући аргумент. Ипак, Карановић се пита да ли је могућ пролазак до истине, те „није ли сваки наш напор осуђен на то да нас заклони и удаљи истину, да послужи тек стварању или усложњавању привида” (Карановић 1997: 10). Када би песнички поглед стигао до истине постојања, указивање те истине окончало би песничку судбину. Преостаје, отуда, још само „пловидба, отворено море, страх и несигурност; али и страст путовања, као и жеља да се ипак угледа некакво копно на видику" (Карановић 1997: 10). Ова пловидба представља осећање онога што је иза - кроз усталасавање вела, којим се свет „отвара у ширину, али и у дубину" (Карановић 1997: 11).

Ако пратимо мали траг везе Колриџа и Карановића, на плану односа садржаја песме и ауторске белешке, опет примећујемо преклапање. Наиме, „Кублај Кан” рефлектује (или започиње) питања о мистериозној природи поетског стварања из Колриџове накнадне белешке: Кублај Кан ствара, у ваздуху, двор и башту са гејзиром из кога куља вода и комадићи стења који недуго затим падају у бездан. У том смислу он представља пандан песника који ствара визионарски или наркотички, а Кублај Каново градитељство, пандан је песниковом стварању: песник - аутор белешке у усамљеној колиби је Кублај Кан иза својих зидина (Перкинс 2010: 42). У другој целини фрагмента, заправо, JА недвосмислено говори о свом жаљењу што не може адекватно речима да сазда ту сунчану дворану Кублај Кана и жуди за музиком абисинијске деве која би га могла надахнути да дворану поетски сазда.

Карановићева песма показује сличну заинтересованост за поетички коментар о пореклу песме, и у том смислу такође покреће или рефлектује исто питање у „Разјасници”: 
Your white hull is gliding along the water.

It seems that

The river is carrying you away with its stream.

But at the hull's bottom

There is an engine, and it makes you move.

With still, steady beats...

(Карановић 2020: 18, 1-6)
Твој бели труп клизи по води.

Чини се да те

Река носи својим током.

Али у дну трупа

Уграђен је мотор, и он те покреће.

Мирним, постојаним дамаром...

(Карановић 2020: 19, 1-6)

Ако нам је дозвољено да се поведемо субјективним утиском (и, откуд уопште секундарном тексту о поезији осећање кривице и стида због изношења субјективних утисака, кад је то, ваљда, његова суштина?), енглески стихови теку магичније и изворније: ова песма стварно постоји у енглеском језику (да непозвани одговоримо на песниково реторско питање; види и утисак о енглеском тексту као иманентнијем песми самој у: Бошковић 2000). И у Колриџовој и у Карановићевој песми, потку метафоре поетске тајне чини река; Колриџова настаје насилно, рекли бисмо готово стереотипно романтичарски, тече силовито и нестаје брзо. Као да песма ламентира краткотрајност тог тајновитог уплива елементарног поетског стварања. Карановићева река тече елегантније и истрајније, мада тим страшније, посебно кад се има у виду њена опустелост на крају песме. Та река не донесе увек бели брод, који носи низводно, док не нестане. А, и Карановићева песма се на крају пита треба ли да ламентира нестанак брода.

Међутим, да река сама носи брод је тек утисак, не сасвим тачан, јер у потпалубљу песме је мотор, који га покреће, тихим али постојаним ритмом. То није метафора неке поједностављене дијалектике techne и enthousiasmos, већ поетска визија односа утиска, посматрача, дистанце, тихе, унутрашње механике скривене од погледа и спољње глаткоће и неодољивости речне матице која доноси и односи. Колриџова репрезентација изградње врта и двора на једној, и реке на другој страни, одсликава сличну, иако грубље представљену дијалектику; угрубо, оно што је градитељ врта и палате код Колриџа, јесу мотор и посматрач код Карановића; и, што је ток између извора и понора код Колриџа, јесте река код Карановића. Код Карановића, како сматра Бошковић (2000), ,jезик је изгубио ствари и стварност, и остао везан само за онога који га емитује" што се бележи потенцијалним, кондиционалним и модалним исказима („Могу да кажем... Могу те сматрати...”) који јасно издвајају гипкост Карановићеве поетике од Колриџове.

Али и на нивоу слике апстраховане од те гипкости, Карановићев посматрач, по претпоставци, песник сам, стоји на обали, одакле само речима контролише реку, брод, али и мотор у њему. Песниково JА, дакле, у тој потенцијално редуцираној слици, није кормилар, нити инжењер - механика је интегрални део метафоре песме, она јој је инхерентна и само је посредно песнику доступна. Ипак, звуци мотора су ти које песник као пера чупа из тела белог лабуд-брода, и та пера механике су оно што остаје за голотињом 
песме, која као таква ишчезава у стиду. Дакле, овде није, или није само, реч о току реке који доноси и односи слутње песме: није то ни апологија, попут оне Милтонове, о грубим прстима што беру недозреле плодове поетолошким значењима прегнантних биљака. Песма нестаје низ реку и дејством песника који је, преводећи је у речи (пера) разголићује, разобличује и губи. На граници на којој песма ишчезава, као на „'обали' непостојања и скривања све је неизвесно, у покрету, лелујаво, трепереће, стално у губитку” (Бошковић 2015: 123). Губитак песме је, дакле, Карановићев и Колриџов заједнички исход поетског стварања. Карановићева поезија и иначе „отвара, са друге стране песништва, питање измакнуте, померене, одлазеће песме... која је увек изнова и никада коначно структурирана у својим траговима" (Бошковић 2013). У том смислу смо, како сматра Бошковић (2013), „сведоци трезвеног поетског сагледавања овако трагичног момента губитка и самообнављања фантома поезије”. Томе бисмо, дакле, додали (или појаснили) да све три целине језичког израза овог губитка, не само нутрином, него својом појавношћу као таквом, не сведоче о узалудности или резигнацији или пустоши. Бошковић (2000) наводи да „семантика материјалних речи не успева у потпуности да прионе уз сенке апсолутних речи, остављајући увек неки мањак у идентификацији". Истовремено, међутим, из губитка, односно недовршености, настаје превод песме на српски језик (који, дакако, не премошћује губитак и не ствара пуноћу смисла и сатисфакције истим). После превода на други језик, на ред долази и превод у други медијум - медијум прозне аутографске белешке. Губици се даље рађају из измицања а њихова сукцесија, сукцесија фантазама песме, постаје врстом језичког одговора на измицање и предметности и стихова.

Међусобно огледање стихова на енглеском језику и њиховог српског „превода” резултује „интерлингвално хибридним обликом” песме „The Ship / Брод” (Брајовић 2017: 140). Какав положај у аутопоетичком хоризонту који уз песме „Тhe ship”, „Брод” чини и прозни запис „Разјасница” - што је, у целини узев, један „од најинтригантнијих текстова новије српске поезије” (Радојчић 1997: 20) - има објаснидбени текст? По самом Карановићу, „Разјасница” са песмом у српској и енглеској верзији „чини извесну целину” и она је „то што јесте: разјасница. Ни мање ни више од тога" (Карановић 1997: 11). Она, дакле, не би требало да буде ефекат ни мистификовања, ни демистификовања песме. „Разјасница” је проширење или продубљивање метафоричности саме песме. Бојана Стојановић-Пантовић трагове аутопоетичке рефлексије у Карановићевом песништву доживљава „као интегрални део његове несвакидашње праксе означавања”, као стално излагање „ризику 'уобличавања значења” наспрамној намери да се „значење прикаже као измицање, расипање, децентрирање средишта песме” (Стојановић Пантовић 1997: 16). Саша Радојчић такође сматра да три текста „представљају једну целину коју у анализи не би требало разлагати" (Радојчић 1997: 20). 
Војислав Карановић потенцира важност читалачког доживљаја, у који, као у луку, песма упловљава. Како је његова поетика повезана „са романтичарским ирационализмом и заносом”, питања у тексту „Разјасница” о простору у којем настаје песма, о статусу надахнућа окренута су колико песнику самом, толико и читаоцима. Песма и прозни текст сугеришу како је простор почетка песме „негде између две варијанте песме, између субјекта и објекта, свести и света”, а то треће подручје „може бити само област језика” (Радојчић 1997: 20). Природа треће области није истоветна ни свести, ни стварима, јер је она размак између њих. Будећи се, поетска свест још се само сећа „исконске блискости постојању коју је искусила будећи се”, па је простор песме коју читамо само сећање, док су принципи односа остали „размакнути”, а у тај се размак, као у простор пловидбе, уметнуо језик. „Песма као брод пролази између обала: субјекта и објекта, свести и света, за свагда растављених и осуђених на узајамну чежњу" (Радојчић 1997: 20). Карановићева аутопоетика хоризонт је на којем је изговорено да су тотална поистовећеност са светом и приступ истини немогући, па се уместо задобијања „'тоталне перцепције”” заиста „морамо задовољити само гледањем доле у провалију, у амбис, упркос чудној ошамућености од које 'настаје поезија"' (Стојановић Пантовић 1997: 19).

Не само да „Разјасница” садржински преговара са мотивом песме / песама, већ завршава сликом која је и вербално изведена тако да наставља претходне реализације: „обе ове песме су у ствари обале а песма је, као брод, само прошла између њих. Оставивши за собом речи да лебде у ваздуху” (Карановић 2020: 21). Дакле, обе песме су фантазми песме, као што је и „Разјасница” фантазам песме. Као аутографска белешка, она је ту да овај закључак изведе и на тај начин доврши процес отеловљења песме или одустајање од истог, које је такође завршетак. Ако песме заиста могу да промаше себе и свој језик - налик томе што „знак може да промаши значење, а синтакса реченицу” - Карановићево дозивање песме значи да ће „њен повратак” ипак бити „само траг њеног поновног губитка, објава лукавства песме да заобиђе текст и нестане" (Бошковић 2015: 123).

Као што превод песме на српски језик представља једновремено и њен коментар, тако и коментар „Разјаснице” представља песму. Као накнадни записи, и песма на српском језику и аутографска белешка модификују првобитни текст. Накнадне аутографске белешке у том смислу имају ефекат супротан ефекту фантомске напомене. Док се, макар на први поглед, сврха фантомске напомене исцрпљује у самопостављању на жртвеник у име потоњег, наводно завршеног или коначног текста, накнадна ауторска белешка као да хоће да натпише публиковани текст, да му се надреди и на неки начин га претвори, макар делом, у фантомски текст, у траг који је ипак претходно доспео до статуса завршеног, објављеног (односно напуштеног). У том смислу, Карановићев „текстуални трилинг” отеловљује собом ванвременску истину поетског, па и поетолошког исказа. 
Карановићева „песма у три слике” показује да се осећај недовршености текста може посматрати и као тангентни аспект процеса сталног исписивања текста чије границе и облик су, открива нам песник, одавно изазване и стављене под знак питања: лингвистички остварени облик песме је „опросторена” артикулација у времену. На неки начин, то је наук предромантичарског померања од текста као производа, готовог, програмираног, ка тексту као процесу, тексту који је у настајању пред нашим очима, о чему је писао Фрај (1956: 145ff). На тај начин, идући ка новим аватарима текста, и Колриџ и Карановић скрећу пажњу на одсуство песме као процеса, који се као такав не може приказати појединачним фантазмом / производом, већ се само може подвргавати новом преговарању, натписивању, поетским или прозним записима и њиховим читањима. У свом завршетку, „Разјасница” тако показује како речи које остају за песмом-бродом ипак нису сувишност којој се нема шта додати. Јер и овај израз рефлексије оставља за собом један прозор, у коме се речи, прихватајући празнину свога непостојања, подижу у ваздух и, као један необичан остатак над празнином, почињу да лебде.

\section{ЗАКљУЧАК}

На границама поетске перспективе, где то да брод клизи постаје то да брод нестаје, а река опусти, стихови показују одсуство као онтолошку вредност песничког искуства. Поузданост је најизвеснија у средишту, али како се „одатле најмање и види”, песник излази на руб општег искуства, па се и Војиславу Карановићу авантура кретања по граници „чини неком врстом предуслова за настанак поезије” (Карановић 1997: 12). А порив за писањем, како о томе говори и Морис Бланшо, одликује управо оно писање „које се сопственом, поступно ослобођеном снагом (алеаторичном снагом одсуства), посвећује себи самом, као нечему што остаје без идентитета и постепено исказује потпуно друкчије могућности" (Бланшо 2012: 83). ${ }^{2}$ Брод који клизи и ишчезава унутар песничког самоостваривања, као и текст „Разјасница”, који гледа у стихове о чијем настанку говори, преиспитује то што гради и то што објашњава, и тако

${ }^{2}$ Бланшо пооштрава параметре ове специјалне страсти, па је писање, онда када се самоостварује у могућностима које су „потпуно друкчије”, ,један анонимни, одгођени и расути однос који оспорава све, најпре идеју Бога, Ја, Субјекта, затим Истине, Једног, те најзад, идеју Књиге и Дела, тако да то писање (схваћено у својој загонетној строгости) не само да више нема циљ у виду Књиге, већ управо представља њен крај: писање за које би се могло рећи да је изван дискурса, изван језика" (Бланшо 2012: 83-84). Иако би једна песничка књига склопом својих представа и појмова афирмисала „примат говора над писањем, примат мисли над језиком”, Бланшо ипак указује на могућност посве друкчијег захтева у коме се писање остварује. На крају уводне белешке за књигу Бесконачни разговори, француски теоретичар управо дозвољава да су писање и порив који га диференцира опредељени напуштањем категорија јединства и поретка, као принципа књиге, али и као принципа културног самопотврђивања. 
неколиким језицима и неколиким поступцима афирмише поезију. Смисао овог преиспитивања у захтеву је за једну пловидбу као за излажење којим се нешто мења у самом писању. Отуда се у песми плови, креће и одлази, али „не да би се идилично вратило унатраг, већ да би се ишло изван, односно, до саме границе, у покушају да се пробије круг, круг свих кругова: тоталитет концепата који чини историју, који се у њој развија, и чији је она развој” (Бланшо 2012: 84).

У извесном смислу, то изван откуда поезија гледа себе саму Карановић упризорује у простору „Разјаснице”. Изван јесте простор упућивања, разумевања, увећања видела у којем, обнажујући се, песме ступају пред читаоце, а у исти мах то јесте и простор у коме се потврђује динамика нецеловитости бића. Говор који разјашњава нешто и о себи нешто чини видљивим. Јер ако говорити у аристотеловском смислу „подразумева - о нечему рећи нешто”, а сваки је говор „састављање и растављање” (Јевремовић 2012: 148), онда текстови разјаснице додирују оно друго себе самих. Из другог се и њихов језик указује као симболичка представа, као један процеп, а не као истина по себи. Чином проласка кроз фантазам распршује се његова обмана, па „субјект прихваћа празнину свога непостојања" (Жижек 2006: 249). Када назремо како оно друго песништва изискује перцептивно и језичко самопрекорачење, почињемо да осећамо како је граница симболичког по којој се клизи у стиховима песме „Брод” једно бићу песме инхерентно превазилажење: „Писање je, са тог становишта, највеће насиље, јер превазилази Закон, сваки закон, па и сопствени" (Бланшо 2012: 84).

Ма колико се умножавао, израз могао бих у песништву Војислава Карановића „не може да успостави знакове и значења”, па се и искуство писања и читања стихова креће „ка једној перманентној сигнификацији која измиче себи самој, ка постмодернистичкој српској поезији у којој више нема ни ноћи, јутра, поднева, предвечерја, јер су све то само ефекти знакова уписани у онтолошки израз непостојања" (Бошковић 2015: 122). Питање којим Војислав Карановић, на крају „Разјаснице” закључује своју аутопоетичку рефлексију у вези са песмама „Брод” и „,Тhe ship” - „где је у овом случају песма?” - изречено је како би се у томе где два језика препознала осујећеност песме као оно о чему појединачни језици као о границама својих могућности певају. А да би се из свести о измицању песме српском и енглеском језику изговорило и питање „где је онда песма?”, које поглед „Разјаснице” отвара за просторност ишчезнућа песме као такве и границе језика по себи. Неуоченост тога што се тражило, неупросторивост у исходу покрета за песмом, оно је што се такође уградило, као парадоксално место, у текст објашњења. Отуда се може записати где, али баш на том коначном и почетном месту потраге, на месту заснивања песме види се како је песма већ другде, док је то што читамо као стихове остало за бићем које је испловило. У свом завршетку „Разјасница” показује како речи које остају за песмом-бродом ипак нису сувишност којој се 
нема шта додати. Јер, кажимо још једном, и овај израз рефлексије оставља за собом један прозор, у коме се речи, прихватајући празнину свога непостојања, подижу у ваздух и, као један необичан остатак над празнином - траг о коме треба мислити и говорити - почињу да лебде.

\section{ИЗВОРИ}

Карановић 2005: В. Карановић, Дах ствари: изабране песме, Чачак: Градска библиотека „Владислав Петковић Дис”.

Карановић 2020: Војислав Карановић, Загрљај у коме нема никога: изабране песме, Београд: Задужбина „Десанка Максимовић”, Народна библиотека Србије.

\section{ЛИТЕРАТУРА}

Бланшо 2012: M. Blanšo, Beskonačni razgovor, Polja, br. 473, 83-84.

Бошковић 2000: D. Bošković, Pesma izvan teksta: Poetički vrtlozi Vojislava Karanovića, Povelja, br. 1, Kraljevo, 97-119.

Бошковић 2013: Д. Бошковић, Карановић: Где је песма?, у: Војислав Карановић, Поезија настаје, изабране песме, Београд: Народна библиотека Србије, 387-403.

Бошковић 2015: D. Bošković, Zablude čitanja, Beograd: Službeni glasnik.

Брајовић 2017: Т. Брајовић, Хибридна песма, Годишъак, год. 12 (2016/2017), Београд: Народна књига, Алфа, 125-159.

Бубања 2015: Никола М. Бубања, ”Ghostbuster's Glee”, Срећа, уредник Драган Бошковић, Крагујевац: Филолошко-уметнички факултет, 201-210.

Жижек 2006: S. Žižek, Škaklivivi subjekt: odsutno središte političke ontologije, preveo s engleskog Dinko Telećan, Sarajevo: „Šahinpašić”.

Јевремовић 1998: P. Jevremović, Psihoanaliza i ontologija, Beograd: Zavod za udžbenike i nastavna sredstva.

Јевремовић 2012: P. Jevremović, Telo, fantazam, simbol, Beograd: Službeni glasnik.

Карановић 1997: V. Karanović, Vojislav Karanović govori za Reč: Stvarnost nije nešto definitivno i dovršeno, razgovarali Tihomir Brajović i Saša Jelenković, Reč, br. 32, 10-15. 
Перкинс 2010: David Perkins, The Imaginative Vision of Kubla Khan: On Coleridge's Introductory Note, in Bloom's Modern Critical Views: Samuel Taylor Coleridge-New Edition, New York: Infobase Publishing.

Радојчић 1997: S. Radojčić, Vojislav Karanović: Subjekat kao polje sila, Reč, br. 32, 19-22.

Радојчић 2005: С. Радојчић, Поезија сумње и поверења: О песништву Војислава Карановића, поговор у: В. Карановић, Дах ствари, 105-112.

Стојановић Пантовић 1997: B. Stojanović-Pantović, Pogled sa ivice: Tragovi autopoetičke refleksije u pesništvu Vojislava Karanovića, Reč, br. $32,16-19$.

Фpaj 1956: Northrop Frye, Towards Defining an Age of Sensibility, ELH, Vol. 23, No. 2, 144-152, The Johns Hopkins University Press.

Фридрих 1969: H. Fridrih, Struktura moderne lirike, Zagreb: Stvarnost.

Хант 1956: Clay Hunt, Donne's Poetry: Essays in Literary Analysis, New Haven: Yale University Press.

Цветић 2011: M. Cvetić, Das Unheimliche: psihoanalitičke i kulturalne teorije prostora, Beograd: Orion Art, Arhitektonski fakultet Univerziteta u Beogradu.

\section{Приручници:}

РМС 2011: Речник српскога језика, Нови Сад: Матица српска.

\section{METAPOETIC NOTES AND PHANTASMS: COLERIDGE'S INTRODUCTORY NOTE TO "KUBLA KHAN" AND "THE EXPOSITORY" BY VOJISLAV KARANOVIĆ}

\section{Summary}

The paper aims to offer a parallel reading of Coleridge's introductory note to Kubla Khan and Vojislav Karanović's "The Expository". Karanović's poem "The Ship", to which "The Expository" harks back, was not only written in English, but was also written following intense reading of English poets. Responding to this queue, the paper examines parallel and conflicting aspects of the two autographic notes, steering the small passages between formidable existing scholarly writing on the issue, moving slightly, if calculatedly, away from the phantom poem - the absolute, lost poem haunting the imagination - toward that poem's (alternative) linguistic materializations - its phantasms. The "slipping away" of the 
phantom poem, the paper argues, gives rise to its several phantasms, including the expository notes, thus opening a window through which words, even if emptied of the phantom poem, rise as the only way of (re)negotiating its slippery nature.

Keywords: Coleridge, Karanović, autopoetics, metapoetics, note, clarification, phantasm, language

Nikola M. Bubanja

Časlav V. Nikolić 